Article

\title{
New Enzyme-Inhibitory Triterpenoid from Marine Macro Brown Alga Padina boergesenii Allender \& Kraft
}

\author{
Liaqat Ali ${ }^{1, *}$, Abdul Latif Khan ${ }^{1}$, Muhammad Al-Broumi ${ }^{1}$, Rashid Al-Harrasi ${ }^{1}$, \\ Lubna Al-Kharusi ${ }^{2}$, Javid Hussain ${ }^{1,3}$ and Ahmed Al-Harrasi 1,3,* \\ 1 UoN Chair of Oman's Medicinal Plants and Marine Natural Products, University of Nizwa, \\ Birkat Al-Mouz, Nizwa-616, Oman; latifepm78@yahoo.co.uk (A.L.K.); albroumi@unizwa.edu.om (M.A.-B.); \\ rashid@unizwa.edu.om (R.A.-H.); javidhej@unizwa.edu.om (J.H.) \\ 2 Marine Science and Fisheries Center, Ministry of Agriculture and Fisheries Resources, Muscat-113, Oman; \\ lubna.alkharusi@gmail.com \\ 3 Department of Biological Sciences and Chemistry, University of Nizwa, Birkat Al-Mauz, Nizwa-616, Oman \\ * Correspondence: malikhejric@gmail.com (L.A.); aharrasi@unizwa.edu.om (A.A.-H.); \\ Tel.: +968-2544-6608 (L.A.); +968-2544-6328 (A.A.-H.)
}

Academic Editor: Sadanandan E. Velu

Received: 3 November 2016; Accepted: 27 December 2016; Published: 18 January 2017

\begin{abstract}
In continuation to our study of the chemical and biological potential of the secondary metabolites isolated from Omani seaweeds, we investigated a marine brown alga, Padina boergesenii. The phytochemical investigation resulted in the isolation of a new secondary metabolite, padinolic acid (1), along with some other semi-pure fractions and sub-fractions. The planar structure was confirmed through MS and NMR (1D and 2D) spectral data. The NOESY experiments coupled with the biogenetic consideration were helpful in assigning the stereochemistry in the molecule. Compound 1 was subjected to enzyme inhibition studies using urease, lipid peroxidase, and alpha-glucosidase enzymes. Compound $\mathbf{1}$ showed low to moderate $\alpha$-glucosidase and urease enzyme inhibition, respectively, and moderate anti-lipid peroxidation activities. The current study indicates the potential of this seaweed and provides the basis for further investigation.
\end{abstract}

Keywords: Padina boergesenii; phytochemical investigation; structure elucidation; enzyme inhibition

\section{Introduction}

Man has been using the oceans as a useful resource for producing economically important materials [1]. During the last 45 years, several bioactive secondary metabolites have been isolated and characterized from various marine organisms [2,3]. These secondary metabolites possess a broad spectrum of activities including antitumor, antiviral, and larvicidal, etc. [4,5], and some of them are in various phases of clinical trials [6]. Brown algae are reported to possess a broad range of bioactive carotenoids, polysaccharides, and polyphenols with physiological effects on human health $[7,8]$. Various secondary metabolites belonging to different classes of compounds have been obtained from brown algal genera and their bioactivities are reported in the literature [9-11].

The secondary metabolites from organisms living in the marine environment have been found to possess ameliorative potential in the exploration of drugs for various human-associated diseases. Ailments such as diabetes are regarded serious metabolic disorders in the human body. This is normally shown as high blood sugar, insulin resistance, and a relative lack of insulin [12]. The figures of the World Health Organization suggest that the worldwide occurrence of diabetes is approximately $9 \%$, which is around $\sim 387$ million people. Approximately $90 \%$ of those with diabetes have type 2 , and the severity of the disease led to about 1.5 million deaths from 2012 to 2014 [13]. Diabetic conditions can 
be suppressed by reducing or blocking the absorption of glucose via inhibiting the related enzymes, such as $\alpha$-glucosidase. Preventing $\alpha$-glucosidase enzyme activity reduces the increase in the sugar level of the blood in response to carbohydrate-rich food intake [14,15]. The postprandial counteraction strategies show the reduced rates of oligosaccharide hydrolyses in the small intestine. This in turn slows the frequency of glucose uptake in the blood cells [16]. In such cases, the application of $\alpha$-glucosidase inhibitors could be an ideal strategy. In this regard, prospects have shown that various terrestrial and aquatic plants possess novel chemical constituents, which could help in inhibiting $\alpha$-glucosidase activity in diabetic conditions [17]. Previously, aquatic- and/or marine-derived plants have been reported to provide potent resources for finding $\alpha$-glucosidase inhibitors, as described by one of our previous communications [18] and those by other researchers [19].

An important source of antioxidants, brown algae play an important role against lipid peroxidation [8]. The common secondary metabolites of brown algae include long-chain fatty acids, polyphenols, polysaccharides, sterols, triterpenoids, and carotenoids, etc., with toxic and curative physiological effects on human health [7]. A major carotenoid of brown algae is fucoxanthin [20], which is an anticancer agent with chemopreventive effects [21]. The brown algal genus Padina is found along the Omani coastal areas, and some of the Padina species are considered important sources of iodine and mannitol [22]. The in vivo anticancer activity and the existence of phenolic compounds have already been reported in P. boergesenii [23]. Furthermore, in a recent study, the hypoglycemic effect and the Ferric Reducing Ability of Plasma (FRAP) activity of the methanolic extract of $P$. boergesenii was also determined [24]. As phytochemical investigations are carried out rarely on P. boergesenii, the present study was conducted to search for secondary metabolites with biological activities. As a result, one new secondary metabolite, padinolic acid (1) (Figure 1), was isolated along with some other semi-pure constituents. The chemical structure was elucidated by the combined spectroscopic studies. The new secondary metabolite $\mathbf{1}$ was also evaluated for potential enzyme-inhibitory activity against lipid peroxidase, $\alpha$-glucosidase, and urease enzymes.

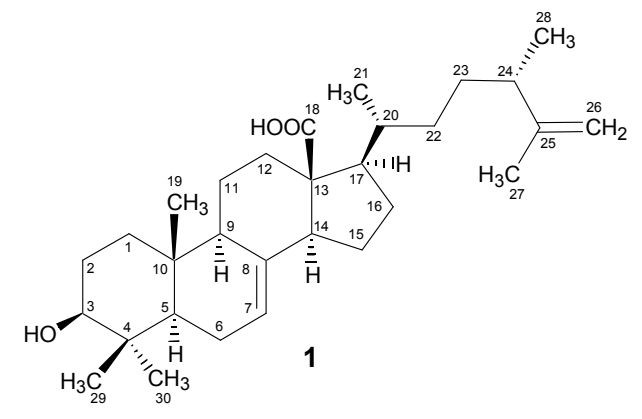

Figure 1. Structure of padinolic acid (1).

\section{Results and Discussion}

\subsection{Structural Characterization}

Compound 1 was separated and purified in the form of amorphous powder by using recycling HPLC. The thin layer chromatography (TLC) plates showed a pink color when heated in the presence of cerric sulphate spray. This observation indicated the terpenoid skeleton in $\mathbf{1}$. The combined analysis of ${ }^{13} \mathrm{C}$ NMR data and FAB-MS proposed the molecular formula $\mathrm{C}_{30} \mathrm{H}_{48} \mathrm{O}_{3}$ for compound $\mathbf{1}$. The FAB-MS data indicated the presence of $p$ seudo-molecular ion peaks at $m / z 457[\mathrm{M}+\mathrm{H}]^{+}$and $m / z 455[\mathrm{M}-\mathrm{H}]^{-}$ for protonated and deprotonated molecular ions, respectively. The molecular formula was further confirmed through high resolution mass spectrometry (HR-ESIMS), which showed the deprotonated molecular ion peak at $m / z 455.3513(\mathrm{M}-1)$. The seven indices of hydrogen deficiency were assigned to the tetracyclic system with two olefinic moieties and one carbonyl group in the molecule. These observations were fully supported by ${ }^{13} \mathrm{C}$ NMR spectral data. 
The prominent fragments in the EI-MS (Figure 2) at $m / z$ 133, 203, and 248 indicated the $\Delta^{7}$-terpenoid skeleton. The EI-MS also showed fragment ion peaks at $m / z 438,412,286$, and 83 corresponding to the hydroxyl group, the carboxylic group, and the alkyl chain in compound 1 . The evidence of retro Diels-Alder fragmentation was provided by the fragment ion peaks at $m / z 316$ and 122, which further supported the $\Delta^{7}$-terpenoid skeleton in 1 . The IR spectrum showed the absorptions for a hydroxyl $\left(3460 \mathrm{~cm}^{-1}\right)$, a carboxylic acid $\left(1705 \mathrm{~cm}^{-1}\right)$, and a trisubstituted double bond $\left(3042,1625\right.$ and $\left.818 \mathrm{~cm}^{-1}\right)$. The ${ }^{1} \mathrm{H}$ NMR spectrum (Table 1) of $\mathbf{1}$ indicated the presence of three tertiary methyls and one secondary methyl at $\delta 0.77$ (s, Me-29), 1.03 (s, Me-19), 1.73 (s, Me-27), and $0.88(\mathrm{~d}, J=5.5 \mathrm{~Hz}, \mathrm{Me}-21)$, respectively. Another tertiary (Me-30) and a secondary (Me-28) methyl group appeared as overlap signals at $\delta 0.97$ to 0.99 . These methyl groups were further confirmed through ${ }^{13} \mathrm{C}$ NMR spectral data, displaying the signals at $\delta 15.1$ (Me-19), 16.1 (Me-29), 16.6 (Me-28), 16.7 (Me-21), 19.5 (Me-27), and 28.6 (Me-30). The olefinic proton (H-7) appeared at $\delta 5.25$ in the form of a multiplet, whereas the $\mathrm{H}-3$ proton (geminal to $\mathrm{OH}$ group) appeared as a multiplet at $\delta$ 3.16. The terminal methylene protons were observed at $\delta 4.62$ and 4.73 (each $\mathrm{d}, J=1.6 \mathrm{~Hz}$ ). These observations were indicative of the terpenoid skeleton in the molecule.

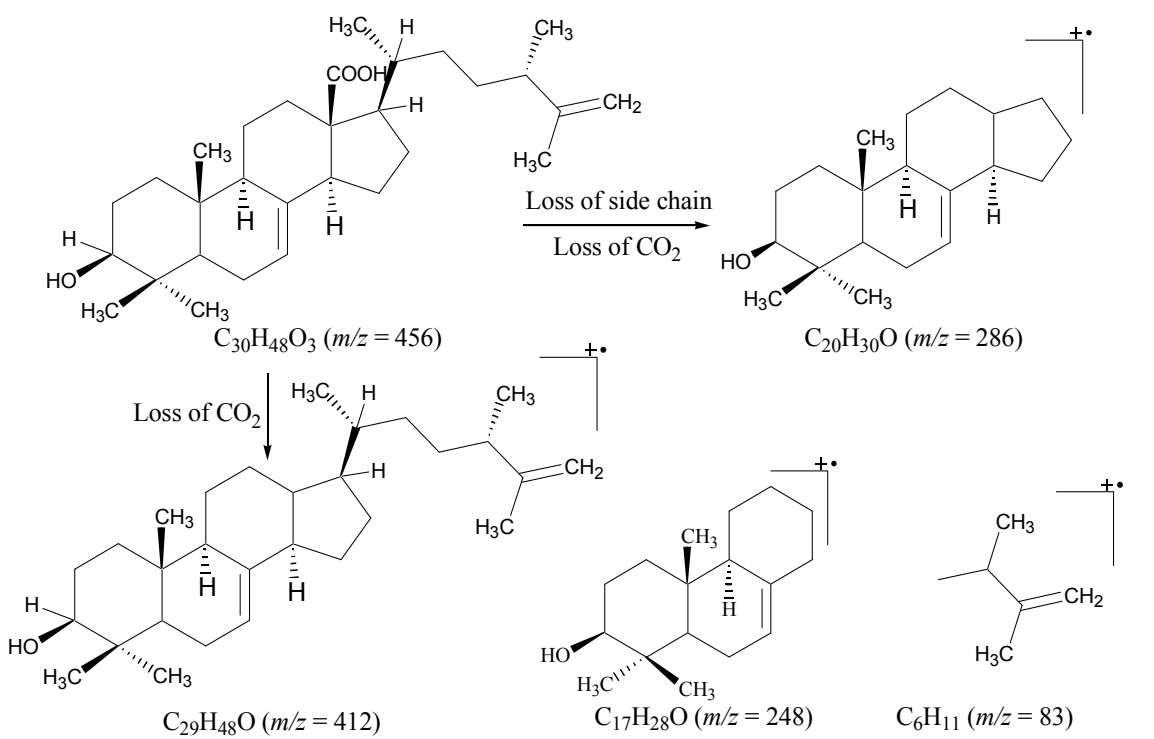

Figure 2. Major MS fragmentation in compound $\mathbf{1 .}$

Table 1. ${ }^{1} \mathrm{H}$ and ${ }^{13} \mathrm{C}$ NMR data (600 and $\left.150 \mathrm{MHz} ; \mathrm{CD}_{3} \mathrm{OD}\right)$ and key HMBC correlations in compound 1.

\begin{tabular}{|c|c|c|c|c|c|c|c|}
\hline C. No. & ${ }^{13} \mathrm{C}(\delta)$ & ${ }^{1} \mathbf{H}(\delta)$ & DEPT & C. No. & ${ }^{13} \mathrm{C}(\delta)$ & ${ }^{1} \mathbf{H}(\delta)$ & DEPT \\
\hline 1 & 40.1 & $0.99, \mathrm{~m} ; 1.71, \mathrm{~m}$ & $\mathrm{CH}_{2}$ & 16 & 31.7 & $1.35, \mathrm{~m}$ & $\mathrm{CH}_{2}$ \\
\hline 2 & 28.0 & $1.57, \mathrm{~m}$ & $\mathrm{CH}_{2}$ & 17 & 50.4 & $1.63, \mathrm{~m}$ & $\mathrm{CH}$ \\
\hline 3 & 79.6 & $3.16, \mathrm{~m}$ & $\mathrm{CH}$ & 18 & 180.1 & - & $\mathrm{C}$ \\
\hline 4 & 41.9 & - & $\mathrm{C}$ & 19 & 15.1 & $1.03, \mathrm{~s}$ & $\mathrm{CH}_{3}$ \\
\hline 5 & 56.9 & $0.73, \mathrm{~m}$ & $\mathrm{CH}$ & 20 & 39.6 & $1.67, \mathrm{~m}$ & $\mathrm{CH}$ \\
\hline 6 & 19.4 & $1.56, \mathrm{~m}$ & $\mathrm{CH}_{2}$ & 21 & 16.7 & $0.88, \mathrm{~d}, J=5.5 \mathrm{~Hz}$ & $\mathrm{CH}_{3}$ \\
\hline 7 & 126.9 & $5.25, \mathrm{~m}$ & $\mathrm{CH}$ & 22 & 35.6 & $1.42, \mathrm{~m}$ & $\mathrm{CH}_{2}$ \\
\hline 8 & 139.7 & - & $\mathrm{C}$ & 23 & 33.3 & $1.52, \mathrm{~m}$ & $\mathrm{CH}_{2}$ \\
\hline 9 & 54.4 & $2.21, \mathrm{~m}$ & $\mathrm{CH}$ & 24 & 40.4 & $2.33, \mathrm{~m}$ & $\mathrm{CH}$ \\
\hline 10 & 38.3 & - & $\mathrm{C}$ & 25 & 152.0 & - & $\mathrm{C}$ \\
\hline 11 & 22.1 & $1.46, \mathrm{~m}$ & $\mathrm{CH}_{2}$ & 26 & 110.2 & $4.62 / 4.73$, each $\mathrm{d}, J=1.6 \mathrm{~Hz}$ & $\mathrm{CH}_{2}$ \\
\hline 12 & 30.8 & $1.94, \mathrm{~m}$ & $\mathrm{CH}_{2}$ & 27 & 19.5 & $1.73, \mathrm{~s}$ & $\mathrm{CH}_{3}$ \\
\hline 13 & 57.5 & - & $\mathrm{C}^{2}$ & 28 & 16.6 & 0.99 , overlap & $\mathrm{CH}_{3}$ \\
\hline 14 & 48.5 & $3.06, \mathrm{~m}$ & $\mathrm{CH}$ & 29 & 16.1 & $0.77, \mathrm{~s}$ & $\mathrm{CH}_{3}$ \\
\hline 15 & 26.9 & $1.08, \mathrm{~m}$ & $\mathrm{CH}_{2}$ & 30 & 28.6 & 0.97 , overlap & $\mathrm{CH}_{3}$ \\
\hline
\end{tabular}


The broadband ${ }^{13} \mathrm{C}$ NMR data for compound $\mathbf{1}$ (Table 1) showed signals for 30 carbons, which were resolved through DEPT experiments into six methyl, 10 methylene, eight methine, and six quaternary carbons. The identity of the side chain was revealed by the signals for one tertiary and two secondary methyl groups along with two methines and three methylenes including a terminal methylene unit. A downfield signal appearing at $\delta 180.1$ was assigned to the quaternary carbon $(\mathrm{O}=\mathrm{C}-18)$ of the carboxylic moiety, whereas the olefinic carbon C-7 and the hydroxyl-bearing carbon C-3 appeared at $\delta$ 126.9 and 79.6, respectively. These observations were also indicative of the $\Delta^{7}$-terpenoid skeleton $[25,26]$ which was further supported by HMBC interactions (Figure 3) in compound 1. The H-3 proton showed HMBC interactions with C-2 ( $\delta 28.0)$ and C-4 ( $\delta 41.9)$; H-7 with C-6 $(\delta 19.4)$ and C-8 ( $\delta 139.7) ; \mathrm{H}-9$ with C-8 $(\delta 139.7), C-10(\delta 38.3)$, and C-11 ( $\delta 22.1)$; the H-14 proton with C-8 ( $\delta 139.7), C-13(\delta 57.5)$, and C-15 ( $\delta 26.9)$; and H-17 with C-13 ( $\delta 57.5), C-18(\delta 180.1)$, and C-20 ( $\delta 39.6)$, thus providing the evidence for the $\Delta^{7}$-terpenoid skeleton as well as the positions of the other groups in the molecule. Hence, the overall structure of compound $\mathbf{1}$ was found to be similar to the ergostane-type triterpenoids reported from various natural resources $[27,28]$.

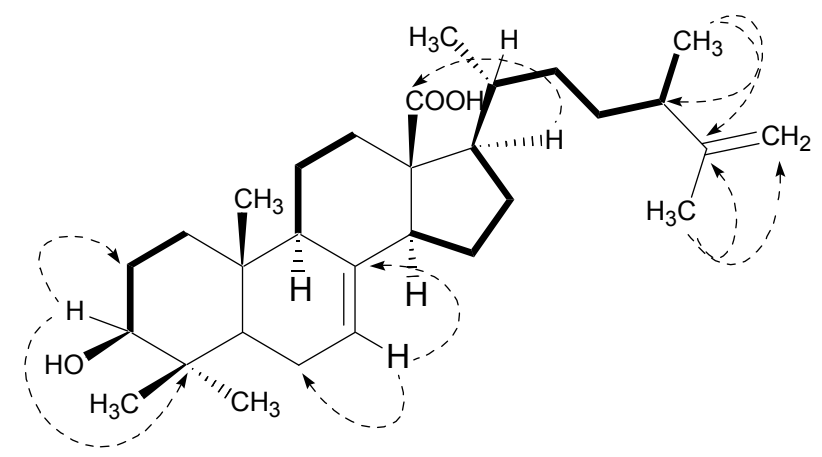

Figure 3. Key COSY (bold) and selected HMBC (arrows) correlations in Compound 1.

After confirmation of the planar structure, the relative stereochemistry of the chiral centers in compound 1 was assigned on the basis of biogenetic consideration coupled with the NOESY experiments. The correlations of H-5, H-9 and H-14 in the NOESY spectrum indicated them to be on the same face of the molecule, whereas the absence of the correlation between H-9 and Me-19 showed the opposite orientation of Me-19 to that of H-9. Hence, coupled with the biogenetic consideration, the trans ring junction at $\mathrm{C}-5 / \mathrm{C}-10$ with the axial orientations of $\mathrm{H}-5$ and $\mathrm{Me}-19$ and the $\beta$-orientation of Me-19 were confirmed (Figure 1). Furthermore, the correlations in the NOESY spectrum were observed in $\mathrm{H}-3 / \mathrm{Me}-30$, indicating these substituents to be on the same face of the molecule. The $\beta$-equatorial position of the $\mathrm{C}-3$ hydroxyl group was thus confirmed based on the $\alpha$-axial orientation of $\mathrm{H}-3$ coupled with the trans ring-junction at C-5/C-10. Thus, the above spectral studies provided evidence to establish the structure of compound 1 as 3-Hydroxy-4,4-dimethylergosta-7,25-dien-18-oic acid, which has been isolated as a new secondary metabolite. This new compound was named padinolic acid (1), in correlation to its producing seaweed Padina boergesenii. The chemical structure of compound $\mathbf{1}$ was similar to the previously reported triterpene sulfates (Antibiotic A-108836) from Fusarium species [29]. Compound 1 contains a carboxylic acid group at the $\mathrm{C}-13$ position, and a terminal methylene unit $\mathrm{CH}_{2}-26$. The carboxylic moiety is lacking in the known metabolite A-108836 whereas the terminal methylene is $\mathrm{CH}_{2}-28$. Furthermore, the hydroxyl at $\mathrm{C}-3$ is in the form of a sulfate, and an additional hydroxyl at C-2 and a methoxy substituent at C-12 are present in the known metabolite [29].

\subsection{Enzyme Inhibition and Anti-Lipid Peroxidation Studies}

Marine algae have adapted themselves to the competitive marine environment [30]. They are considered as the renewable sources of a number of secondary metabolites including cyclic peptides, polyketides, steroids, terpenoids, and alkaloids, etc., possessing a broad spectrum of interesting 
biological activities [31]. Therefore, compound $\mathbf{1}(10,50$ and $100 \mu \mathrm{g} / \mathrm{mL})$ isolated from P. boergesenii was subjected to enzyme ( $\alpha$-glucosidase and urease) inhibition and lipid peroxidation evaluation.

The results indicated that compound 1 showed a significantly higher $(p<0.0001)$ dose-dependent anti-lipid peroxidation potential (Figure 4). At the maximum concentration $\left(100 \mu \mathrm{g} \cdot \mathrm{mL}^{-1}\right)$, compound 1 showed the highest anti-lipid peroxidation $(46.27 \% ; p<0.0001)$. The two-way ANOVA also suggested that with the increase in the concentration of the compound, the effect is significantly higher $(p<0.0005)$. However, this activity was lower than that of the known standard butyl hydroxy toluene $(\sim 82.72 \%)$. In the case of $\alpha$-glucosidase enzyme inhibition, compound 1 showed a dose-dependent activity $\left(10<50<100 \mu \mathrm{g} \cdot \mathrm{mL}^{-1}\right)$. Furthermore, compound 1 showed a meager suppression of urease enzyme activity. Importantly, both enzyme inhibition patterns were similar; however, the levels of the activities were significantly lower than the standards (acrabose and thiourea; Figure 4).
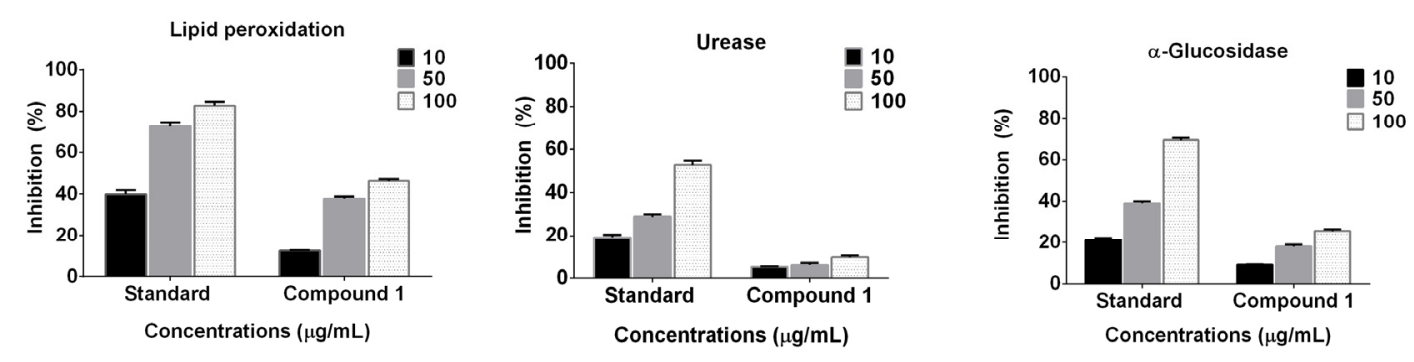

Figure 4. Enzyme ( $\alpha$-glucosidase and urease) inhibition and lipid peroxidation potential of compound 1; the values in the bar are the means of three replications presented with the standard error.

\section{Material and Methods}

\subsection{General Experimental Procedures}

Optical rotation for compound 1 was measured on a DIP 360 polarimeter (JASCO, Tokyo, Japan). IR spectrum was recorded on a spectrophotometer with ATR-Tensor 37 by Bruker. JMS HX 110 Mass spectrometer (JEOL, Freising, Germany) was used to acquire the mass spectra. ${ }^{1} \mathrm{H}$ and ${ }^{13} \mathrm{C}$ NMR spectra were recorded on AM 600 NMR spectrometer (Bruker, Fallanden, Switzerland), and the chemical shift values were recorded in ppm $(\delta)$ units, whereas the coupling constants $(J)$ were reported in $\mathrm{Hz}$. The Final purification of compound 1 was carried out by using recycling HPLC (JAI), and chloroform was used as the mobile phase in a series of two silica columns; JAIGEL-1H and JAIGEL-2H (Serial No. J60-3E13, JAI, Yokohama, Japan). The TLC experiments were carried out on aluminum sheets pre-coated with 60F-254 silica gel (E. Merck, Darmstadt, Germany), which were developed in a mobile phase of $1 \% \mathrm{MeOH} /$ dichloromethane to $5 \% \mathrm{MeOH} /$ dichloromethane. The developed TLC plates were then sprayed in ceric sulphate and heated to observe the UV-inactive compounds.

\subsection{Plant Material}

P. boergesenii Allender \& Kraft (Phaeophyceae) was collected from Gulf of Oman near coastal areas of Sur $\left(22^{\circ} 34^{\prime} 0^{\prime \prime} \mathrm{N} ; 59^{\circ} 31^{\prime} 44^{\prime \prime} \mathrm{E}\right)$ during March 2014, and the sample identification was carried out by Dr. Lubna Al-Kharusi, Marine Science and Fisheries Center, Ministry of Agriculture and Fisheries Resources, Sultanate of Oman.

\subsection{Extraction and Isolation}

The fresh seaweed samples were washed with tap water and then freeze-dried. The dried material $(750 \mathrm{~g})$ was powdered and extracted with methanol at room temperature to get $110 \mathrm{~g}$ of the crude residue. The repeated silica gel column chromatography of the crude extract afforded fourteen fractions at various polarity of $n$-hexane, dichloromethane/ $n$-hexane, and methanol/dichloromethane. The sub-fraction \#7 (9.5 g), eluted at dichloromethane/methanol (90:10), was further purified through 
recycling HPLC in a silica column $(1 \mathrm{H} / 2 \mathrm{H})$ running in $3.5 \mathrm{~mL} \cdot \mathrm{min}^{-1}$ flow rate of chloroform (containing $0.5 \%$ ethanol as stabilizer). The sample was recycled five times and compound $\mathbf{1}(5.5 \mathrm{mg})$ was purified with a retention time of $41 \mathrm{~min}$.

Padinolic Acid (1)

Colorless powder (5.5 mg); $[\alpha]_{\mathrm{D}}^{25}+5.9$ (c 0.0007, MeOH); IR (KBr): $v_{\max } 3460,3042,1705,1625$, and 818 . ${ }^{1} \mathrm{H}$ NMR $\left(600 \mathrm{MHz}, \mathrm{CD}_{3} \mathrm{OD}\right)$ : See Table $1 ;{ }^{13} \mathrm{C}$ NMR $\left(150 \mathrm{MHz}, \mathrm{CD}_{3} \mathrm{OD}\right)$ : See Table 1; EI-MS (70 eV): $m / z$ (rel. int.) $456[\mathrm{M}]^{+}$(12), $438\left[\mathrm{M}^{+}-\mathrm{H}_{2} \mathrm{O}\right](3), 412\left[\mathrm{M}^{+}-\mathrm{CO}_{2}\right]$ (2), 286 (6), 248 (100), 203 (47), 133 (44), 83 (16); (+)FAB-MS: $m / z 457[\mathrm{M}+\mathrm{H}]^{+}$; (-)FAB-MS: $m / z 455$ [M - H] $]^{-}$; HRESI-MS: $m / z 455.3513$ $[\mathrm{M}-\mathrm{H}]^{-}$(calcd. for $\mathrm{C}_{30} \mathrm{H}_{47} \mathrm{O}_{3}, 455.3520$ ).

\subsection{Enzyme Inhibition and Anti-Lipid Peroxidation Assay}

The $\alpha$-glucosidase enzyme (E.C.3.2.1.20; from Saccharomyces cerevisiae) inhibition assay was performed as described in the method of Oki et al. [32]. The rate of inhibition of the enzyme was measured through ELISA microplate spectrophotometer (xMark, Bio-Rad, Hercules, CA, USA) at $400 \mathrm{~nm}$. The reaction containing $p$-nitrophenyl $\alpha$-D-glucopyranoside (PNP-G; $0.7 \mathrm{mM}$ ) as a substrate, 2.0 units $/ \mathrm{mL} \alpha$-glucosidase enzyme and sodium phosphate buffer $(50 \mathrm{mM}, 100 \mathrm{mM} \mathrm{NaCl}, \mathrm{pH} 7.4)$ was prepared with or without sample. The reaction initiated by incubation at $37^{\circ} \mathrm{C}$ for $30 \mathrm{~min}$. The rate of hydrolysis in PNP-G by $\alpha$-glucosidase was recorded on ELISA every $30 \mathrm{~s}$.

Besides that, the inhibition potential of the isolated compound for another important enzyme urease was undertaken according to the method of Golbabaei et al. [33]. In brief, a reaction mixture containing urease (Jack bean, Sigma, Hamburg, Germany; $20 \mathrm{mg} / \mathrm{mL} ; 25 \mu \mathrm{L})$, urea (100 mM; $55 \mu \mathrm{L})$, phosphate buffer $\left(\mathrm{K}_{2} \mathrm{HPO}_{4} \cdot 3 \mathrm{H}_{2} \mathrm{O} 100 \mathrm{mM}\right.$; EDTA $1.0 \mathrm{mM}, \mathrm{LiCl}_{2} 10 \mathrm{mM}$; $\mathrm{pH}$ 8.2) and various concentrations of compound $\left(10-100 \mu \mathrm{g} / \mathrm{mL}\right.$ ) were incubated at $37^{\circ} \mathrm{C}$ for $30 \mathrm{~min}$ in 96 -well microplate. An indophenol method was used, where the ultimate product (ammonia) was used to monitor urease inhibition activity of the tested compound. The reaction further continued by adding the phenol reagent $(1 \%$ phenol $(w / v)$ and $0.005 \%$ sodium nitroprusside $(w / v) ; 45 \mu \mathrm{L})$ and alkali reagent $(0.1 \%$ $\mathrm{NaOCl} ; 0.5 \%$ sodium hydroxide; $70 \mu \mathrm{L}$ ) into the wells. The mixture was incubated at $37^{\circ} \mathrm{C}$ for $30 \mathrm{~min}$ which was followed by recording the absorbance at $630 \mathrm{~nm}$ on ELISA microplate reader (xMark, Biorad, Irvine, CA, USA). All the enzyme inhibition assays were repeated three times. The inhibition percentage was calculated through: Inhibitory activity $(\%)=100-($ ODtest well/ODcontrol $) \times 100$. Thiourea and acrabose were used as the standard inhibitor for urease and $\alpha$-glucosidase enzymes, respectively, whereas a blank was used as a negative control. The same concentrations of compound 1 and the standard were used to compare the activity.

In addition to enzyme inhibition, the isolated compound was also analyzed for inhibiting the level of lipid peroxidation. This was performed by a modified method of thiobarbituric acid reactive substances (TBARS) [34]. Using in vitro test conditions, the peroxidation of liposome (phosphatidyl-choline, Sigma, Hamburg, Germany; $50 \mathrm{mg} / \mathrm{mL}$ ) was initiated by adding iron chloride $(0.001 \mathrm{mM} ; 200 \mu \mathrm{L})$, potassium chloride $(300 \mathrm{mM} ; 200 \mu \mathrm{L})$ and the test compound $(50 \mu \mathrm{L})$. The peroxidation was initiated by ascorbic acid $(0.001 \mathrm{M} ; 125 \mu \mathrm{L})$, where the reaction mixture was then incubated for $30 \mathrm{~min}$ at $37^{\circ} \mathrm{C}$. Trichloroacetic acid (10\% and $0.38 \%$ TBA) were added. The glass vials containing the reactants were kept at $95^{\circ} \mathrm{C}$ in water bath to initiate boiling status for one hour. The resultant change in pink color was recorded on ELISA at $535 \mathrm{~nm}$ absorbance. A blank without compound was used as negative control while butyl hydroxy toluene (BHT) was used as positive control. The $\%$ inhibition was calculated by using the formula IP\% $=\left(1-A_{t} / A_{o}\right) \times 100$; where $A_{t}$ and $A_{o}$ are the absorbances for compound and control. The experiment was repeated three times.

A two-way ANOVA analysis of the mean values of three replicates was also performed to understand the significance $(p<0.05)$ of concentration vs. activity using GraphPad Prism v6.01 (Software Inc., San Diego, CA, USA). 


\section{Conclusions}

The search for new sources of natural products is one of the important steps in the drug discovery process. In the current study, the macroalga P. boergesenii was studied comprehensively to investigate the presence of biologically active secondary metabolites. Subsequent to chromatographic extraction and spectroscopic identification, compound $\mathbf{1}$ was evaluated for potential enzyme inhibition studies. Results indicated that compound 1 possesses low to moderate urease, anti-lipid peroxidation and $\alpha$-glucosidase inhibition activity, respectively, as compared to the known standards. These findings suggest that seaweed species can be considered as a potential resource for novel bioactive secondary metabolites and future therapeutic agents which cannot be synthesized easily but possess high activity against human ailments.

Acknowledgments: The financial support was provided partly by the University of Nizwa through the funded project (A/13-14-UON/09/Chair MPMNP/IF).

Author Contributions: Liaqat Ali, Ahmed Al-Harrasi and Javid Hussain conceived and designed the study; Liaqat Ali and Abdul Latif Khan performed the experiments and wrote the manuscript; Muhammad Al-Broumi, Rashid Al-Harrasi and Lubna Al-Kharusi collected and identified the marine samples and did the preliminary studies. All authors read and approved the final manuscript.

Conflicts of Interest: The authors declare no conflict of interest.

\section{References}

1. Elsayed, K.N.; Radwan, M.M.; Hassan, S.H.; Abdelhameed, M.S.; Ibraheem, I.B.; Ross, S.A. Phytochemical and biological studies on some Egyptian seaweeds. Nat. Prod. Commun. 2012, 7, 1209-1210. [PubMed]

2. Kim, S.K.; Karagozlu, M.Z. Marine algae: Natural product source for gastrointestinal cancer treatment. Adv. Food Nutr. Res. 2011, 64, 225-233. [PubMed]

3. Kim, S.K.; Ta, Q.V. Potential beneficial effects of marine algal sterols on human health. Adv. Food Nutr. Res. 2011, 64, 191-198. [PubMed]

4. Ayyad, S.E.; Slama, M.O.; Mokhtar, A.H.; Anter, A.F. Cytotoxic bicyclic diterpene from brown alga Sargassum crispum. Boll. Chim. Farm. 2001, 140, 155-159. [PubMed]

5. $\quad$ Tang, H.F.; Yang-Hua, Y.; Yao, X.S.; Xu, Q.Z.; Zhang, S.Y.; Lin, H.W. Bioactive steroids from the brown alga Sargassum carpophyllum. J. Asian Nat. Prod. Res. 2002, 4, 95-101. [CrossRef] [PubMed]

6. Blunden, G. Biologically active compounds from marine organisms. Phytother. Res. 2001, 15, 89-94. [CrossRef] [PubMed]

7. Karthikeyan, R.; Somasundaram, S.T.; Manivasagam, T.; Balasubramanian, T.; Anantharaman, P. Hepatoprotective activity of brown alga Padina boergesenii against $\mathrm{CCl}_{4}$ induced oxidative damage in Wistar rats. Asian Pac. J. Trop. Med. 2010, 3, 696-701. [CrossRef]

8. Amsler, C.D.; Fairhead, V.A. Defensive and sensory chemical ecology of brown algae. Adv. Bot. Res. 2006, 43, $1-91$.

9. Fukuyama, Y.; Kodama, M.; Miura, I.; Kinzyo, Z.; Mori, H.; Nakayama, Y.; Takahashi, M. Anti-plasmin inhibitor. VI. Structure of phlorofuco-furoeckol A, a novel phlorotannin with both dibenzo-1,4-dioxin and dibenzofuran elements from Ecklonia kurome. Chem. Pharm. Bull. 1990, 38, 133-135. [CrossRef] [PubMed]

10. Suqiura, Y.; Matsuda, K.; Yamada, Y.; Nishikawa, M.; Shioya, K.; Katsuzaki, H.; Imai, K.; Amano, H. Isolation of a new anti-allergic phlorotannin, phlorofucofuroeckol B, from an edible brown alga, Eisenia arborea. Biosci. Biotechnol. Biochem. 2006, 70, 2807-2811. [CrossRef] [PubMed]

11. Ham, Y.M.; Baik, J.S.; Hyun, J.W.; Lee, N.H. Isolation of a new phlorotannin, fucodiphlorethol G, from a brown alga, Ecklonia cava. Bull. Korean Chem. Soc. 2007, 28, 1595-1597.

12. Kumar, S.; Narwal, S.; Kumar, V.; Prakash, O. $\alpha$-Glucosidase inhibitors from plants: A natural approach to treat diabetes. Pharmacogn. Rev. 2011, 5, 19-29. [CrossRef] [PubMed]

13. Global Health Estimates: Deaths by Cause, Age, Sex and Country, 2000-2012; World Health Organization: Geneva, Switzerland, 2014.

14. Kim, K.Y.; Nam, K.A.; Kurihara, H.; Kim, S.M. Potent $\alpha$-glucosidase inhibitors purified from the red alga Grateloupia elliptica. Phytochemistry 2008, 69, 2820-2825. [CrossRef] [PubMed]

15. Kalra, S. Alpha glucosidase inhibitors. J. Pak. Med. Assoc. 2014, 64, 474-476. [PubMed] 
16. Wehmeier, U.F.; Piepersberg, W. Biotechnology and molecular biology of the alpha-glucosidase inhibitor acarbose. Appl. Microbiol. Biotechnol. 2004, 63, 613-625. [CrossRef] [PubMed]

17. Bischoff, H. Pharmacology of $\alpha$-glucosidase inhibition. Eur. J. Clin. Investig. 1994, 24, 3-10.

18. Ali, L.; Khan, A.L.; Al-Kharusi, L.; Hussain, J.; Al-Harrasi, A. New $\alpha$-glucosidase inhibitory triterpenic acid from marine macro green alga Codium dwarkense. Mar. Drugs 2015, 13, 4344-4356. [CrossRef] [PubMed]

19. Li, X.; Fan, X.; Han, L.; Lou, Q.; Yan, X.; Zhang, Y. Screening for alpha-glucosidase inhibitors from the macroalgal extracts. Chin. J. Mar. Drugs 2002, 21, 8-11.

20. Okuzumi, J.; Takahashi, T.; Yamane, T.; Kitao, Y.; Inagake, M.; Ohya, K.; Nishino, H.; Tanaka, Y. Inhibitory effects of fucoxanthin, a natural carotenoid, on $N$-ethyl- $N^{\prime}$-nitro- $N$-nitrosoguanidine induced mouse duodenal carcinogenesis. Cancer Lett. 1993, 68, 159-168. [CrossRef]

21. Kim, J.M.; Araki, S.; Kim, D.J.; Park, C.B.; Takasuka, N.; Baba-Toriyama, H.; Ota, T.; Nir, Z.; Khachik, F.; Shimidzu, N.; et al. Chemopreventive effects of carotenoids and curcumins on mouse colon carcinogenesis after 1,2-dimethylhydrazine initiation. Carcinogenesis 1998, 19, 81-85. [CrossRef] [PubMed]

22. Vasuki, S.; Ganesan, M.; Rao, P.V.S. Effect of light intensity, photoperiod, ESP medium and nitrogen sources on growth of marine brown alga Padina boergesenii (Dictyotales, Phaeophyta). Indian J. Geo-Mar. Sci. 2001, 30, 228-231.

23. Karthikeyan, R.; Manivasagam, T.; Anantharaman, P.; Balasubramanian, T.; Somasundaram, S.T. Chemopreventive effect of Padina boergesenii on ferric nitrilotriacetate (Fe-NTA)-induced oxidative damage in Wistar rats. J. Appl. Phycol. 2011, 23, 257-263. [CrossRef]

24. Permeh, P.; Gohari, A.; Saeidnia, S.; Jamili, S.; Permeh, S.; Mostafavi, P.G. Alpha amylase inhibitory and antioxidant activity of Padina boergesenii (Allander and Kraft) from Persian Gulf. Planta Med. 2013, 79. [CrossRef]

25. Hong, Z.L.; Xiong, J.; Wu, S.B.; Zhu, J.J.; Hong, J.L.; Zhao, Y.; Xia, G.; Hu, J.F. Tetracyclic triterpenoids and terpenylated coumarins from the bark of Ailanthus altissima ("Tree of Heaven"). Phytochemistry 2013, 86, 159-167. [CrossRef] [PubMed]

26. Hpu, Y.; Cao, S.; Brodie, P.J.; Miller, J.S.; Birkinshaw, C.; Andrianjafy, M.N.; Andriantsiferana, R.; Rasamison, V.E.; TenDyke, K.; Shen, Y.; et al. Euphane triterpenoids of Cassipourea lanceolata from the Madagascar rainforest. Phytochemistry 2010, 71, 669-674.

27. Liu, D.Z. A review of ergostane and cucurbitane triterpenoids of mushroom origin. Nat. Prod. Res. 2014, 28, 1099-1105. [CrossRef] [PubMed]

28. Wu, S.J.; Leu, Y.L.; Chen, C.H.; Chao, C.H.; Shen, D.Y.; Chan, H.H.; Lee, E.J.; Wu, T.S.; Wang, Y.H.; Shen, Y.C. Camphoratins A-J, potent cytotoxic and anti-inflammatory triterpenoids from the fruiting body of Taiwanofungus camphorates. J. Nat. Prod. 2010, 73, 1756-1762. [CrossRef] [PubMed]

29. Brill, G.M.; Kati, W.M.; Montgomery, D.; Karwowski, J.P.; Humphrey, P.E.; Jackson, M.; Clement, J.J.; Kadam, S.; Chen, R.H.; McAlpine, J.B. Novel triterpene sulfates from Fusarium compactum using a rhinovirus 3C protease inhibitor screen. J. Antibiot. 1996, 49, 541-546. [CrossRef] [PubMed]

30. Harnedy, P.A.; FitzGerald, R.J. Bioactive proteins, peptides, and amino acids from macroalgae. J. Phycol. 2011, 47, 218-232. [CrossRef] [PubMed]

31. Srikong, W.; Mittraparp-arthorn, P.; Rattanaporn, O.; Bovornreungroj, N.; Bovornreungroj, P. Antimicrobial activity of seaweed extracts from Pattani, southeast cost of Thailand. Food Appl. Biosci. J. 2015, 3, 39-49.

32. Oki, T.; Matsumoto, T.; Osajima, Y. Inhibitory effect of alpha-glucosidase inhibitors varies according to its origin. J. Agric. Food Chem. 1999, 47, 550-553. [CrossRef] [PubMed]

33. Golbabaei, S.; Bazl, R.; Golestanian, S.; Nabati, R.; Omrany, R.B.; Yousefi, B.; Hajiaghaee, R.; Rezazadeh, S.; Amanlou, M. Urease inhibitory activities of $\beta$-boswellic acid derivatives. Daru 2013, 21. [CrossRef] [PubMed]

34. Gulati, V.; Harding, I.H.; Palombo, E.A. Enzyme inhibitory and antioxidant activities of traditional medicinal plants: Potential application in the management of hyperglycemia. BMC Complemnt. Altern. Med. 2012, 12. [CrossRef] [PubMed]

(C) 2017 by the authors; licensee MDPI, Basel, Switzerland. This article is an open access article distributed under the terms and conditions of the Creative Commons Attribution (CC-BY) license (http://creativecommons.org/licenses/by/4.0/). 